\title{
Characteristics of prosthetic treatment needs in patients with history of myocardial infarction and in general population based on topographic and occluso- morphological classification of missing teeth
}

\section{Charakterystyka potrzeb leczenia protetycznego u pacjentów po zawale mięśnia sercowego oraz w populacji ogólnej na podstawie topograficznej oraz okluzyjno-morfologicznej klasyfikacji braków zębowych}

\author{
Bartlomiej Górski', Marcin Szerszeń ${ }^{2}$ \\ ${ }^{1}$ Zakład Chorób Błony Śluzowej i Przyzębia, Warszawski Uniwersytet Medyczny \\ Department of Periodontal and Oral Mucosa Diseases, Medical University of Warsaw \\ Head: prof. dr hab. n. med. Renata Górska \\ ${ }^{2}$ Katedra Protetyki Stomatologicznej, Warszawski Uniwersytet Medyczny \\ Chair of Prosthodontics, Medical University of Warsaw \\ Head: prof. dr hab. n. med. Elżbieta Mierzwińska-Nastalska
}

KEY WORDS:

prosthetic treatment needs, myocardial infarction, tooth loss classification

\section{Summary}

Introduction. The relationship between oral diseases and general health for decades has been the subject of many studies. One of the most frequently discussed subjects is the correlation between periodontitis and cardiovascular diseases. Periodontal diseases are the second most common cause of tooth loss in adults.

Aim of the study. The aim of the study was to present the characteristics of prosthetic treatment needs of patients hospitalized with MI and in the general population based on GalasiniskaLandsbergerowa and Eichner classifications of tooth loss.

Material and methods. The study group included 151 patients hospitalized in the $1^{\text {st }}$ Department of Cardiology, Medical University of Warsaw, admitted to the ward with MI. The control group included 160 patients, who were selected from the general population.

Results. The results indicate increased needs
HASŁA INDEKSOWE: potrzeby leczenia protetycznego, zawał mięśnia sercowego, klasyfikacja braków zębowych

\section{Streszczenie}

Wstep. Związek pomiędzy chorobami jamy ustnej a zdrowiem ogólnym byt $i$ jest nadal przedmiotem wielu badań. Jednym z częściej podejmowanych tematów jest zwiazek pomiędzy stanami zapalnymi przyzębia a chorobami sercowo-naczyniowymi. Zapalenia przyzębia sa druga najczęstsza przyczyna utraty zębów u dorostych.

Cel pracy. Celem pracy byto przedstawienie charakterystyki potrzeb leczenia protetycznego $u$ pacjentów hospitalizowanych z powodu zawatu mięśnia sercowego (MI) oraz w populacji ogólnej na podstawie klasyfikacji wg Galasińskiej-Landsbergerowej oraz wg Eichnera.

Material i metody. Do grupy badanej wtaczono 151 pacjentów hospitalizowanych $w$ I Katedrze $i$ Klinice Kardiologii Warszawskiego Uniwersytetu Medycznego, przyjętych na oddziat z powodu MI. Do grupy kontrolnej właczono 160 pacjentów, które wytoniono spośród osób wylosowanych $z$ populacji ogólnej. 
of prosthetic treatment in the study group in comparison with the control group, both in view of Galasińska-Landsbergerowa and Eichner classification.

Conclusions. It has been revealed, that the state of dentition in patients in the study group and in the control group was alarming.

\section{Introduction}

The relationship between oral diseases and general health has been the subject of many studies for decades. One of the most frequently discussed subjects is the correlation between periodontitis and cardiovascular diseases (CVD). ${ }^{1}$ Scientific research has shown that the relative risk of CVD in patients with periodontitis varies from 1.24 to $1.34 .^{2}$ This risk increases to 1.44 in people below the age of 65 years. ${ }^{3}$ In 2010, cardiovascular diseases were responsible for $46.0 \%$ of all deaths of Poles (40.8\% males and $51.8 \%$ females) ${ }^{4}$ The most common cause of death was ischemic heart disease (including myocardial infarction - 17.8 thousand, i.e. $10 \%$ of deaths of all cardiovascular causes).

The prevalence of periodontitis increases with age. ${ }^{5}$ Among adult Poles aged over 65 years, more than $40 \%$ of people have moderate or advanced periodontitis. ${ }^{6}$ For patients with history of myocardial infarction, these data are even more worrying. Włosowicz et al. observed the occurrence of advanced periodontitis in $41 \%$ of patients after MI, and Bochniak et al. in $65.1 \%$ of such patients. ${ }^{7,8}$ Absence of functional dentition was observed in $11 \%$ of rural residents, while the percentage of edentulous people aged 65-74 years concerns about $28.9 \%$ of this population. Among patients after MI, the percentage of edentate patients was approximately $30 \% .^{6,7,9}$ Periodontitis is the second most common cause of tooth loss
Wyniki. Wyniki wskazuja zwiększone potrzeby leczenia protetycznego $w$ grupie badanej $w$ stosunku do grupy kontrolnej $w$ odniesieniu do klasyfikacji wg Galasińskiej-Landsbergerowej $i$ wg Eichnera.

Wnioski. Stan uzębienia u pacjentów w grupie zarówno badanej, jak i kontrolnej jest również alarmujacy.

\section{Wprowadzenie}

Związek pomiędzy chorobami jamy ustnej a zdrowiem ogólnym był i jest nadal przedmiotem wielu badań. Jednym z częściej podejmowanych tematów jest związek pomiędzy stanami zapalnymi przyzębia a chorobami sercowo-naczyniowymi (CVD). ${ }^{1}$ Badania naukowe wykazały, że ryzyko względne wystąpienia CVD u pacjentów z zapaleniem przyzębia waha się od 1,24 do 1,34. ${ }^{2}$ Ryzyko to wzrasta do 1,44 u osób poniżej 65 roku życia. ${ }^{3}$ Choroby układu krążenia w 2010 roku były odpowiedzialne za 46,0\% ogółu zgonów Polaków (40,8\% zgonów mężczyzn i 51,8\% zgonów kobiet). ${ }^{4}$ Najczęstszą przyczyną zgonów była choroba niedokrwienna serca (w tym zawał mięśnia sercowego (MI) 17,8 tys., a więc odpowiednio $10 \%$ zgonów z powodu ogółu przyczyn krążeniowych).

Częstość występowania zapalenia przyzębia rośnie wraz z wiekiem. ${ }^{5}$ Wśród dorosłych Polaków powyżej 65 roku życia u ponad $40 \%$ osób stwierdza się występowanie średniozaawansowanego lub zaawansowanego zapalenia przyzębia. ${ }^{6} \mathrm{~W}$ odniesieniu do pacjentów po MI dane te są jeszcze bardziej niepokojące. Włosowicz i wsp. zaobserwowali występowanie zaawansowanego zapalenia przyzębia u $41 \%$ pacjentów po MI, a Bochniak i wsp. aż u $65,1 \%$ chorych. ${ }^{7,8}$

Brak funkcjonalnego uzębienia zaobserwowano u $11 \%$ mieszkańców terenów wiejskich, natomiast odsetek osób bezzębnych w wieku 65-74 lat w poszczególnych regionach kraju dotyczy 
in adults. ${ }^{10}$ Teeth deficiencies, on the other hand, are the main indication for prosthetic therapy and oral cavity rehabilitation as an integral part of restoration of the whole organism. In order to pre-assess the needs of prosthetic treatment, many classifications of missing teeth are used. These classifications form the basis of prosthetic diagnostics and are helpful in the choice of treatment methods, however, bearing in mind their limitations they are not, and should not be, a determinant when the treatment method is selected. ${ }^{11,12}$ However, when the prosthetic treatment needs are assessed,not for a particular patient, but for a population sample, they seem to be a good material for statistical comparisons.

\section{Aim of the study}

The study presents prosthetic treatment needs of patients hospitalized with MI and those in the general population based on GalasińskaLandsbergerowa and Eichner classifications.

\section{Material and methods}

In order to compare prosthetic treatment needs, dental examinations were carried out in two groups of people, which were defined as a test group and a control one. A total of 151 patients (35 women, 116 men) with an average age of $55( \pm 8.0)$ years were included in the study group. They were patients hospitalized in the $1^{\text {st }}$ Department of Cardiology of the Medical University of Warsaw admitted to the department because of MI. The control group included 160 patients (97 women, 63 men) with an average age of $55.2( \pm 10.0)$ years, who were randomly selected from the general population by the Ministry of Internal Affairs and Administration. Adults $<70$ years old were allocated to these two groups. Only people who did not report history of MI in the interview were qualified to the control group. Patients około $28,9 \%$ populacji. Wśród pacjentów po MI wskaźnik bezzębia wyniósł około 30\%.6,7,9

Zapalenia przyzębia są drugą najczęstszą przyczyną utraty zębów u dorosłych. ${ }^{10}$ Braki zębowe natomiast, są głównym wskazaniem do terapii protetycznej oraz rehabilitacji jamy ustnej jako integralnej części całego organizmu. W celu wstępnej oceny potrzeb leczenia protetycznego stosuje się wiele klasyfikacji braków zębowych. Klasyfikacje te stanowią podstawy diagnostyki protetycznej i są pomocne przy wyborze metod leczenia, jednak biorąc pod uwagę ich ograniczenia nie są i nie powinny być determinantą rozstrzygającą o sposobie leczenia. ${ }^{11,12} \mathrm{~W}$ odniesieniu jednak do oceny potrzeb leczenia protetycznego nie u konkretnego pacjenta, lecz w grupie osób wydają się dobrym materiałem do porównań statystycznych.

\section{Cel pracy}

W badaniu przedstawiono charakterystykę potrzeb leczenia protetycznego u pacjentów hospitalizowanych $\mathrm{z}$ powodu MI oraz w populacji ogólnej na podstawie klasyfikacji wg Galasińskiej-Landsbergerowej oraz wg Eichnera.

\section{Material i metody}

W celu porównania potrzeb leczenia protetycznego przeprowadzono badania stomatologiczne w dwóch grupach osób, które określono jako grupa badana oraz grupa kontrolna. Do grupy badanej włączono 151 pacjentów (35 kobiet, 116 mężczyzn) o średniej wieku 55 $( \pm 8,0)$ lat. Byli to pacjenci hospitalizowani w I Katedrze i Klinice Kardiologii Warszawskiego Uniwersytetu Medycznego przyjęci na oddział z powodu MI. Do grupy kontrolnej włączono 160 pacjentów (97 kobiet, 63 mężczyzn) o średniej wieku 55,2 $( \pm 10,0)$ lat, które wyłoniono spośród osób wylosowanych z populacji ogólnej przez Ministerstwo Spraw Wewnętrznych 
with neoplastic diseases, autoimmune diseases, chronic kidney disease in the $4^{\text {th }}$ and $5^{\text {th }}$ stage, rheumatic diseases, chronic liver diseases and with history of brain stroke were excluded from either group. Individuals included in the control group were examined in the Department of Periodontology and Oral Diseases, Medical University of Warsaw. In addition to the general dental examination, periodontal examination was also performed. Anamnesis included questions about selected socioeconomic indicators and habits. All participants in the study signed a statement of informed consent, which was issued by the Bioethics Committee of the Medical University of Warsaw (opinion No. KB-145/2011).

Two classifications were used to assess missing teeth: topographic classification according to Galasińska-Landsbergerowa dividing the deficiencies into five classes (the maxilla and the mandible are classified separately) (Tab. 1), and occlusomorphological classification according to Eichner dividing teeth deficiencies into groups and subgroups (the maxilla and the mandible assessed in mutual relationship) (Tab. 2). In the Eichner classification, four support zones within the lateral teeth during maximum intercuspation (two zones in molars, two zones in premolars) are the criteria for division into individual groups. The number of zones with the distribution of the residual teeth enables allocation to a specific subgroup. During the process of classifying patients to specific classes, groups and subgroups, third molars were not considered, except for those that were involved in determining the support zone. It has been assumed that the support zone is designated when teeth from the opposing arches contact each other in a way that establishes the vertical dimension of occlusion (VDO). During the classification process, residual roots with necrotic pulp were assessed as a missing tooth. The classification process i Administracji. Do obu grup zakwalifikowane zostały osoby dorosłe poniżej 70-tego roku życia. Do grupy kontrolnej zakwalifikowane zostały tylko te osoby, które w wywiadzie nie zgłaszały MI. Z obu grup wykluczono pacjentów z chorobami nowotworowymi, chorobami autoimmunologicznymi, przewlekłymi chorobami nerek w 4 i 5 stadium, chorobami reumatycznymi, przewlekłymi schorzeniami wątroby oraz po przebytym udarze mózgu. Osoby włączone do grupy kontrolnej były badane w Zakładzie Chorób Błony Śluzowej i Przyzębia WUM. Oprócz ogólnego badania stomatologicznego, przeprowadzono również badanie periodontologiczne. Anamneza zawierała pytania dotyczące niektórych wskaźników socjoekonomicznych oraz nawyków. Wszyscy uczestnicy badania wyrazili zgodę na jego przeprowadzenie, przez podpisanie oświadczenia świadomej zgody, które zostało wydane przez Komisję Bioetyczną WUM (opinia nr KB-145/2011).

Do oceny braków zębowych wykorzystane zostały dwie klasyfikacje. Klasyfikacja topograficzna wg Galasińskiej-Landsbergerowej dzieląca braki na pięć klas (szczęka i żuchwa są klasyfikowane oddzielnie) (tab. 1) oraz klasyfikacja okluzyjno-morfologiczna wg Eichnera dzieląca braki na grupy oraz podgrupy (szczęka i żuchwa oceniana we wzajemnej relacji) (tab. 2). W klasyfikacji wg Eichnera cztery strefy podparcia w obrębie zębów bocznych podczas maksymalnej interkuspidacji (dwie strefy w zębach trzonowych, dwie strefy w zębach przedtrzonowych) są kryterium podziału na poszczególne grupy. Ilość stref wraz z rozmieszczeniem zębów umożliwia przyporządkowanie do konkretnej podgrupy. Podczas procesu klasyfikacji pacjentów do konkretnych klas, grup i podgrup nie brane były pod uwagę zęby ósme, za wyjątkiem tych, które brały udział w ustaleniu strefy podparcia. Przyjęto, iż strefa podparcia wyznaczona jest wtedy, kiedy zęby z przeciwstawnych łuków kontaktują się ze sobą w sposób ustalający wysokość zwarcia. Korzenie z miazgą w 
Ta b le 1. Topographic classification of missing teeth acc. to Galasińska-Landsbergerowa

\begin{tabular}{|c|l|l||}
\hline \multicolumn{2}{|c|}{ Szczęka i żuchwa klasyfikowane oddzielnie } \\
\hline Klasa & \multicolumn{1}{|c|}{ Opis Klasy } & \multicolumn{1}{|c|}{ Możliwości leczenia protetycznego } \\
\hline I & $\begin{array}{l}\text { Braki jakościowe w jednym lub więcej } \\
\text { zębach, przy pełnych łukach zębowych }\end{array}$ & Nakłady, wkłady, korony, licówki \\
\hline II & Braki międzyzębowe & $\begin{array}{l}\text { Implantoprotetyka, mosty, protezy ruchome } \\
\text { (podparte lub osiadające) }\end{array}$ \\
\hline III & Braki skrzydłowe jedno- lub obustronne & $\begin{array}{l}\text { Implantoprotetyka, protezy ruchome } \\
\text { (podparte lub osiadające) }\end{array}$ \\
\hline IV & $\begin{array}{l}\text { Braki różnorodne - połączenie braków } \\
\text { międzyzębowych i skrzydłowych }\end{array}$ & $\begin{array}{l}\text { Implantoprotetyka, mosty, protezy ruchome } \\
\text { (podparte lub osiadające) }\end{array}$ \\
\hline V & $\begin{array}{l}\text { Braki całkowite } \\
\text { Implantoprotetyka, protezy ruchome } \\
\text { (osiadające) }\end{array}$ \\
\hline
\end{tabular}

Ta b le 2. Occlusal-morphological classification of missing teeth acc. to Eichner

\begin{tabular}{|c|c|c|c|}
\hline Grupa & Opis grupy & Podgrupa & Opis podgrupy \\
\hline \multirow[t]{3}{*}{ A } & \multirow{3}{*}{$\begin{array}{l}\text { Przeciwstawne kontakty między } \\
\text { zębami górnymi i dolnymi } \\
\text { występują we wszystkich } \\
\text { czterech strefach podparcia }\end{array}$} & A1 & Szczęka i żuchwa w pełni uzębione \\
\hline & & A2 & $\begin{array}{l}\text { Jeden brak międzyzębowy w szczęce lub } \\
\text { żuchwie }\end{array}$ \\
\hline & & $\mathrm{A} 3$ & $\begin{array}{l}\text { Liczne braki międzyzębowe i międzyzębo- } \\
\text { wo-skrzydłowe }\end{array}$ \\
\hline \multirow[t]{4}{*}{ B } & \multirow{4}{*}{$\begin{array}{l}\text { Przeciwstawne kontakty między } \\
\text { zębami górnymi i dolnymi nie } \\
\text { występują we wszystkich } \\
\text { czterech strefach podparcia }\end{array}$} & B1 & Zachowane trzy strefy podparcia \\
\hline & & $\mathrm{B} 2$ & Zachowane dwie strefy podparcia \\
\hline & & B3 & Zachowana jedna strefa podparcia \\
\hline & & B4 & $\begin{array}{l}\text { Kontakty zębów przeciwstawnych poza stre- } \\
\text { fami podparcia (w zakresie zębów przednich) }\end{array}$ \\
\hline \multirow[t]{3}{*}{$\mathrm{C}$} & \multirow{3}{*}{$\begin{array}{l}\text { Nie ma kontaktów między } \\
\text { zębami przeciwstawnymi } \\
\text { górnymi i dolnymi }\end{array}$} & $\mathrm{C} 1$ & $\begin{array}{l}\text { Częściowo zachowane zęby w szczęce i żu- } \\
\text { chwie bez wzajemnych kontaktów }\end{array}$ \\
\hline & & $\mathrm{C} 2$ & $\begin{array}{l}\text { W jednym łuku zęby zachowane, } \\
\text { w łuku przeciwstawnym brak zębów }\end{array}$ \\
\hline & & $\mathrm{C} 3$ & Bezzębna szczęka i żuchwa \\
\hline
\end{tabular}

did not take into account the current prosthetic treatment and if the type and structure of the prosthesis allowed it, patients were asked to remove it during the intraoral examination. Patients with full dental arches (excluding third molars) were classified according to Class I of Galasińska-Landsbergerowa and stanie zgorzelinowego rozpadu podczas procesu klasyfikacji były oceniane jako brak zęba. W procesie klasyfikacji nie brano pod uwagę dotychczasowego leczenia protetycznego i jeśli pozwalał na to rodzaj i konstrukcja protezy pacjenci byli proszeni o usunięcie uzupełnienia z jamy ustnej podczas badania wewnątrzustnego. 
A1 subgroup acc. to Eichner, including those patients who did not need prosthetic treatment, or potential treatment would be limited to qualitative but not quantitative restorations. Authors in this study did not take into account orthodontic defects.

Statistical analysis was performed in PQStat program (PQStat Software). Due to the characteristics of the assessed variables, non-parametric tests were used in the analysis. In this study, Pearson compatibility test - $\chi^{2}$ was used for qualitative variables, U MannWhitney tests was used for quantitative variables. Statistical significance level was set at $\mathrm{p}<0.05$.

\section{Results}

Using the Galasińska-Landsbergerowa classification for the assessment of the upper dental arch, the study group had a higher percentage of patients with quantitative deficiencies compared with the control group (the test group - 94\%, the control group $82.5 \%$ ). Characteristics of maxillary missing teeth indicates the majority of Class IV in the study group ( $\mathrm{n}=71,47.3 \%)$ compared to the majority of Class II in the control group $(n=62$, $38.8 \%$ ). The comparison of individual classes of missing teeth in the upper jaw determines the increased needs of prosthetic treatment in the study group and the differences in all five classes were statistically significant (Table 3, Part A).

In the topographic classification in the mandible, the study group also had more quantitative deficiencies (93.3\% to $86.9 \%$ ) compared to the control group. More than half of the patients in the study group were classified in Class IV and V; in the control group, the highest percentage of patients had deficiencies classified in Class II according to Galasińska-Landsbergerowa. Differences between groups in Class I and III were not
Pacjenci z pełnymi łukami zębowymi (wyłączając zęby ósme) byli klasyfikowani odpowiednio do I klasy Galasińskiej-Landsbergerowej oraz A1 podgrupy Eichnera z włączeniem tych pacjentów, którzy leczenia protetycznego nie potrzebowali lub potencjalne leczenie ograniczałoby się do uzupełnień braków jakościowych a nie ilościowych zębów. W badaniu nie brano pod uwagę wad ortodontycznych.

Analizę statystyczną przeprowadzono z użyciem programu PQStat (PQStat Software). $\mathrm{Z}$ uwagi na charakterystykę ocenianych zmiennych w analizie wykorzystano testy nieparametryczne. W przypadku zmiennych jakościowych stosowano test zgodności Pearsona $-\chi^{2}$, dla zmiennych ilościowych testy U MannaWhitneya. Poziom istotności statystycznej wyznaczono na $\mathrm{p}<0,05$.

\section{Wyniki}

Wykorzystując klasyfikację wg GalasińskiejLandsbergerowej do oceny górnego łuku zębowego, grupa badana posiadała większy odsetek pacjentów z brakami ilościowymi w porównaniu do grupy kontrolnej (grupa badana - 94\%, grupa kontrolna-82,5\%). Charakterystyka braków zębowych szczęki wskazuje większość braków mieszanych - międzyzębowo-skrzydłowych (IV klasa) w grupie badanej ( $\mathrm{n}=71,47,3 \%)$ w porównaniu do większości braków międzyzębowych (II klasa) w grupie kontrolnej ( $\mathrm{n}=62,38,8 \%$ ). Porównanie poszczególnych klas braków zębowych w szczęce determinuje zwiększone potrzeby leczenia protetycznego $\mathrm{w}$ grupie badanej a różnice we wszystkich pięciu klasach były istotne statystycznie (tab. 3 część A). W klasyfikacji topograficznej $\mathrm{w}$ żuchwie grupa badana $\mathrm{w}$ porównaniu do grupy kontrolnej również posiadała więcej braków ilościowych (93,3\% do 86,9\%). Więcej niż połowa pacjentów w grupie badanej została sklasyfikowana w klasie IV i V, w grupie kontrolnej największy odsetek pacjentów posiadało braki międzyzębowe sklasyfikowane 
Tab le 3. Results according to Galasińska-Landsbergerowa classification

\begin{tabular}{|c|c|c|c|c|}
\hline & \multicolumn{4}{|c|}{ Klasyfikacja topograficzna wg Galasińskiej-Landsbergerowej } \\
\hline & Klasa braków zębowych & Grupa badana (n, \%) & Grupa kontrolna (n, \%) & $\mathrm{p}$ (test $\chi 2)$ \\
\hline & \multicolumn{4}{|c|}{ Szczęka } \\
\hline \multirow{6}{*}{ Część A } & I & $9(6,0 \%)$ & $28(17,5 \%)$ & 0,002 \\
\hline & II & $15(10,0 \%)$ & $62(38,8 \%)$ & $<0,001$ \\
\hline & III & $20(13,3 \%)$ & $10(6,3 \%)$ & 0,035 \\
\hline & IV & $71(47,3 \%)$ & $51(31,9 \%)$ & 0,005 \\
\hline & V & $35(23,3 \%)$ & $9(5,6 \%)$ & $<0,001$ \\
\hline & \multicolumn{4}{|c|}{ Żuchwa } \\
\hline \multirow{5}{*}{ Część B } & I & $10(6,7 \%)$ & $21(13,1 \%)$ & 0,058 \\
\hline & II & $16(10,7 \%)$ & $52(32,5 \%)$ & $<0,001$ \\
\hline & III & $36(24,0 \%)$ & $44(27,5 \%)$ & 0,482 \\
\hline & IV & $68(45,3 \%)$ & $38(23,8 \%)$ & $<0,001$ \\
\hline & V & $20(13,3 \%)$ & $5(3,1 \%)$ & 0,001 \\
\hline
\end{tabular}

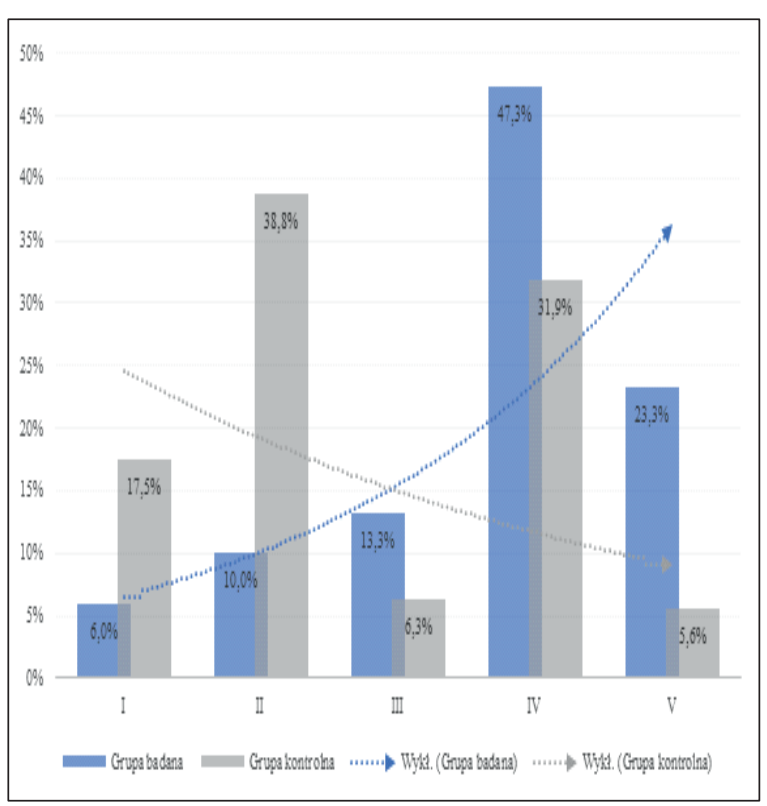

Fig. 1. Distribution of percentages of individual classes in the study group and the control group according to Galasińska-Landsbergerowa classification in the maxilla.

Ryc. 1. Rozkład wartości procentowych poszczególnych klas braków zębowych dla grupy badanej $i$ grupy kontrolnej $z$ wykorzystaniem klasyfikacji wg Galasińskiej-Landsbergerowej dotyczacy szczęki.

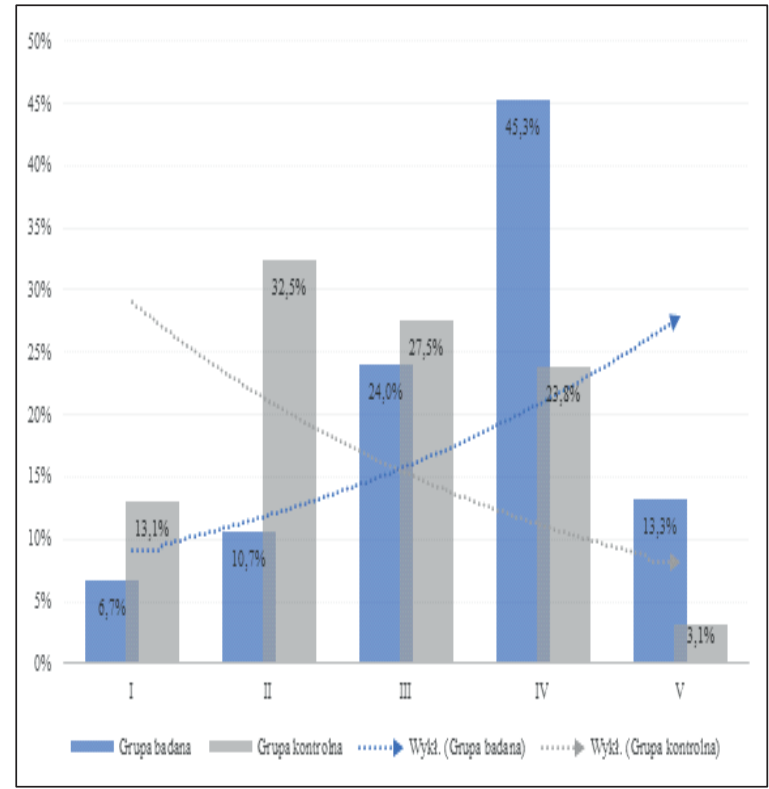

Fig. 2. Distribution of percentages of individual classes in the study group and the control group according to Galasińska-Landsbergerowa classification in the mandible.

Ryc. 2. Rozkład wartości procentowych poszczególnych klas braków zębowych dla grupy badanej $i$ grupy kontrolnej $z$ wykorzystaniem klasyfikacji wg Galasińskiej-Landsbergerowej dotyczacy żuchwy. 
statistically significant, in the remaining three classes, statistical significance was demonstrated (Table 3, Part B). The distribution of percentages of individual classes in the study and the control groups is presented in diagrams (Fig. 1 - the maxilla, Fig. 2 the mandible). The graphs were additionally supported with exponential trend lines for both groups showing the shift in the missing teeth characteristics of the test group towards Class IV and V according to GalasińskaLandsbergerowa classification both in the maxilla and in the mandible.

Using the occluso-morphological classification according to Eichner, the study and the control groups were first of all analysed in terms of assignment to general groups (groups A, B, C) (Figure 3), and then to the relevant subgroups (A1-3, B1-4, C1-3) (Table 4, Figure 4). A total of 24 patients from the study group were allocated to group A, which corresponded to only $16 \%$ of the whole group. The difference in the A group according to the Eichner classification between the study and the control groups was statistically significant. In the control group, 68 patients were classified in category $\mathrm{A}$, which was $42.5 \%$ of the whole group. Considering the division into subgroups only in subgroup A1, the significance coefficient was greater than 0.05 . In the remaining subgroups, the representatives of the study group were few in comparison with the control group (A2 $2 \%$ to $11.3 \%$, A $3-12 \%$ to $25 \%$ ). In Eichner's group B, the largest number of patients from both the study and the control group were classified, and their percentages were similar to $50 \%$ ( $48 \%$ and $50.6 \%$, respectively). In group $\mathrm{B}, \mathrm{p}$ determined on the basis of the $\chi^{2}$ test reached the value furthest from the level of statistical significance, which also correlated with statistical analyses for particular subgroups (B2-B4). The difference in the number of classified patients from the study w II klasie wg Galasińskiej-Landsbergerowej. Różnice pomiędzy grupami w klasie I i III nie były istotne statystycznie, w pozostałych trzech klasach wykazano istotność statystyczną (tab. 3 część B). Rozkład wartości procentowych poszczególnych klas $\mathrm{w}$ grupie badanej i grupie kontrolnej został przedstawiony na wykresach (ryc. 1 - szczęka, ryc. 2 - żuchwa). Wykresy zostały dodatkowo wzbogacone o wykładnicze linie trendu dla obu grup obrazujące przesunięcie charakterystyki braków zębowych grupy badanej w kierunku IV i V klasy wg GalasińskiejLandsbergerowej zarówno w szczęce, jak i w żuchwie.

Wykorzystując klasyfikację okluzyjno-morfologiczną wg Eichnera grupa badana i grupa kontrolna zostały przeanalizowane pod kątem przyporządkowania $\mathrm{w}$ pierwszej kolejności do grup ogólnych (grupy A, B, C) (ryc. 3), a następnie do odpowiednich podgrup (A1-3, B14, C1-3)(tab. 4, ryc. 4). W grupie A znalazło się 24 pacjentów z grupy badanej co odpowiadało $16 \%$ całości tej grupy. Różnica w grupie A wg klasyfikacji Eichnera pomiędzy grupą badaną a grupą kontrolną była istotna statystycznie. W grupie kontrolnej w kategorii A zostało sklasyfikowanych 68 pacjentów, czyli 42,5\% całej grupy. Rozpatrując podział na podgrupy jedynie w podgrupie A1 współczynnik istotności był większy niż 0,05 . W pozostałych podgrupach przedstawiciele grupy badanej byli nieliczni $\mathrm{w}$ porównaniu $\mathrm{z}$ grupą kontrolną (A2 - $2 \%$ do $11,3 \%$, A $3-12 \%$ do $25 \%$ ). W grupie B wg Eichnera zostało sklasyfikowanych zdecydowanie najwięcej pacjentów zarówno z grupy badanej, jak i z grupy kontrolnej a ich wartości procentowe były zbliżone 50\% (48\% pacjentów z grupy badanej, $50,6 \%$ pacjentów $\mathrm{z}$ grupy kontrolnej). W grupie $B$, $p$ wyznaczone na podstawie testu $\chi^{2}$ osiągnęło wartość najbardziej oddaloną od progu istotności, co korelowało również z analizami statystycznymi dla poszczególnych podgrup (B2-B4). Różnica w liczebności sklasyfikowanych pacjentów $\mathrm{z}$ grupy badanej 
Ta ble 4. Results according to Eichner classification

\begin{tabular}{|c|c|c|c|c|c|c|c|}
\hline \multicolumn{8}{|c|}{ Klasyfikacja okluzyjno-morfologiczna wg Eichnera } \\
\hline $\begin{array}{c}\text { Grupa } \\
\text { braków } \\
\text { zębowych }\end{array}$ & $\begin{array}{c}\text { Grupa } \\
\text { badana } \\
(\mathrm{n}, \%)\end{array}$ & $\begin{array}{c}\text { Grupa } \\
\text { kontrolna } \\
(\mathrm{n}, \%)\end{array}$ & $\begin{array}{c}\mathrm{p} \\
\text { (test } \chi 2 \text { ) }\end{array}$ & $\begin{array}{l}\text { Podgrupa } \\
\text { braków } \\
\text { zębowych }\end{array}$ & $\begin{array}{c}\text { Grupa } \\
\text { badana } \\
(\mathrm{n}, \%)\end{array}$ & $\begin{array}{c}\text { Grupa } \\
\text { kontrolna } \\
(\mathrm{n}, \%)\end{array}$ & $\begin{array}{c}\mathrm{p} \\
\text { (test } \chi 2)\end{array}$ \\
\hline \multirow{3}{*}{ A } & \multirow{3}{*}{$\begin{array}{c}24 \\
(16,0 \%)\end{array}$} & \multirow{3}{*}{$\begin{array}{c}68 \\
(42,5 \%)\end{array}$} & \multirow{3}{*}{$<0,001$} & A1 & $3(2,0 \%)$ & $10(6,3 \%)$ & 0,062 \\
\hline & & & & A 2 & $3(2,0 \%)$ & $18(11,3 \%)$ & 0,001 \\
\hline & & & & A3 & $18(12,0 \%)$ & $40(25,0 \%)$ & 0,003 \\
\hline \multirow{4}{*}{ B } & \multirow{4}{*}{$\begin{array}{c}72 \\
(48,0 \%)\end{array}$} & \multirow{4}{*}{$\begin{array}{c}81 \\
(50,6 \%)\end{array}$} & \multirow{4}{*}{0,644} & B1 & $12(8,0 \%)$ & $30(18,8 \%)$ & 0,006 \\
\hline & & & & B2 & $22(14,7 \%)$ & $19(11,9 \%)$ & 0,468 \\
\hline & & & & B3 & $15(10,0 \%)$ & $9(5,6 \%)$ & 0,150 \\
\hline & & & & B4 & $23(15,3 \%)$ & $23(14,4 \%)$ & 0,813 \\
\hline \multirow{3}{*}{$\mathrm{C}$} & \multirow{3}{*}{$\begin{array}{c}54 \\
(36,0 \%)\end{array}$} & \multirow{3}{*}{$\begin{array}{c}11 \\
(6,9 \%)\end{array}$} & \multirow{3}{*}{$<0,001$} & $\mathrm{C} 1$ & $17(11,3 \%)$ & $1(0,6 \%)$ & $<0,001$ \\
\hline & & & & $\mathrm{C} 2$ & $19(12,7 \%)$ & $6(3,8 \%)$ & 0,004 \\
\hline & & & & $\mathrm{C} 3$ & $18(12,0 \%)$ & $4(2,5 \%)$ & 0,001 \\
\hline
\end{tabular}

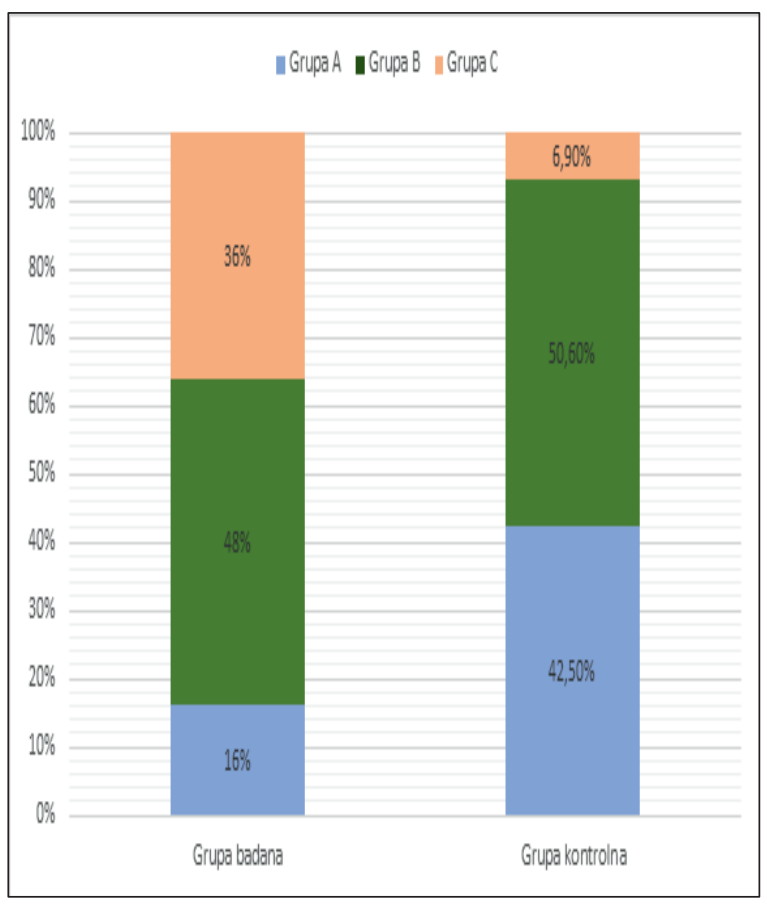

Fig. 3. Distribution of percentages of individual missing teeth group in the study and control group according to Eichner classification.

Ryc. 3. Rozktad wartości procentowych poszczególnych grup braków zębowych dla grupy badanej i grupy kontrolnej z wykorzystaniem klasyfikacji wg Eichnera.

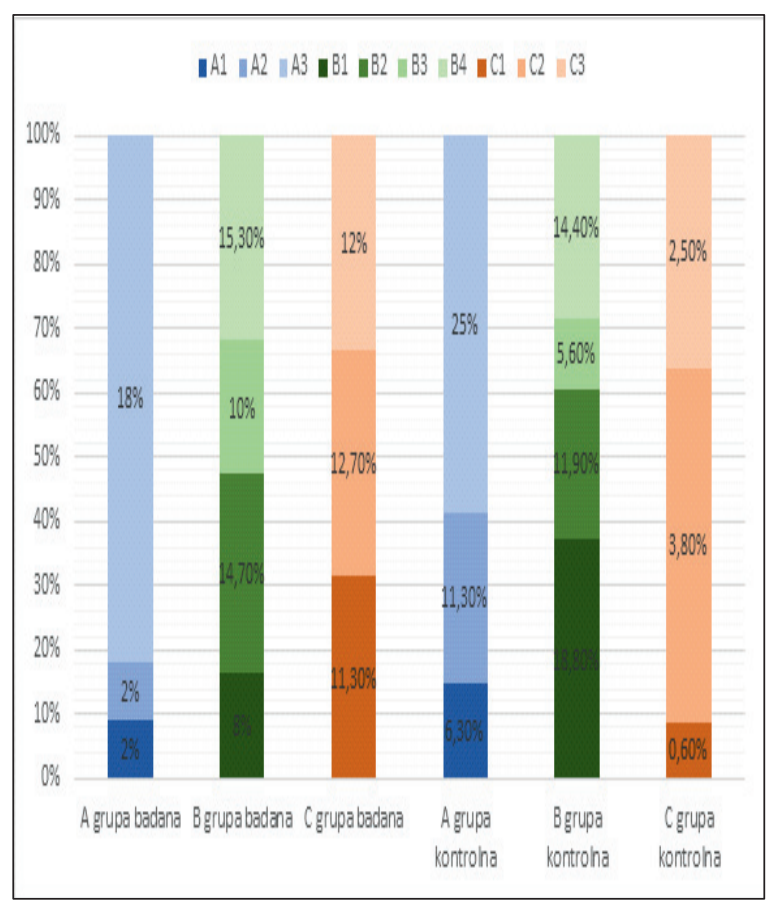

Fig. 4. Distribution of percentages of individual missing teeth subgroup in the study and control group according to Eichner classification.

Ryc. 4. Rozktad wartości procentowych poszczególnych podgrup braków zębowych dla grupy badanej $i$ grupy kontrolnej $z$ wykorzystaniem klasyfikacji wg Eichnera. 
Table 5. Study and control group characteristics

\begin{tabular}{|c|c|c|c|}
\hline Zmienna & $\begin{array}{l}\text { Grupa badana } \\
(\mathrm{N}=151)\end{array}$ & $\begin{array}{l}\text { Grupa kontrolna } \\
\qquad(\mathrm{N}=160)\end{array}$ & $\mathrm{P}^{*}$ \\
\hline $\begin{array}{l}\text { Płeć (n, \%) (sex) } \\
\text { kobieta (woman) } \\
\text { mężczyzna (man) }\end{array}$ & $\begin{array}{c}35(23,2) \\
116(76,8)\end{array}$ & $\begin{array}{l}97(60,6) \\
63(39,4)\end{array}$ & $<0,0001$ \\
\hline Wiek (średnia \pm SD) (age) & $55,0 \pm 8,0$ & $55,2 \pm 10,0$ & 0,4513 \\
\hline $\begin{array}{l}\text { Wykształcenie (education) } \\
\text { podstawowe (primary) } \\
\text { średnie (secondary) } \\
\text { wyższe (higher) }\end{array}$ & $\begin{array}{l}53(35,3) \\
69(46,0) \\
28(18,7)\end{array}$ & $\begin{array}{l}11(6,9) \\
66(41,2) \\
83(51,9)\end{array}$ & $<0,0001$ \\
\hline $\begin{array}{l}\text { Dochód (earnings) } \\
<800 \text { pln } \\
800-1500 \text { pln } \\
>1500 \text { pln }\end{array}$ & $\begin{array}{c}46(30,7) \\
57(38) \\
47(31,3)\end{array}$ & $\begin{array}{l}20(12,5) \\
42(26,2) \\
98(61,2)\end{array}$ & $<0,0001$ \\
\hline Palenie tytoniu (n, \%) (smoking) & $96(63,57)$ & $29(18,1)$ & $<0,0001$ \\
\hline Nadciśnienie tętnicze (n, \%) (hypertention) & $116(76,82)$ & $52(32,5)$ & $<0,0001$ \\
\hline Cukrzyca (n, \%) (diabets) & $33(21,85)$ & $10(6,2)$ & $<0,0001$ \\
\hline
\end{tabular}

Ta b le 6. Periodontal examination results of study and control group

\begin{tabular}{|l|c|c|c|}
\hline \multicolumn{1}{|c|}{ Zmienna } & Grupa badana $(\mathrm{N}=151)$ & Grupa kontrolna $(\mathrm{N}=160)$ & $\mathrm{P}$ \\
\hline Liczba zębów (średnia) & 17 & 24 & $<0,0001^{*}$ \\
\hline PI (średnia $\pm \mathrm{SD})(\%)$ & $85,7 \pm 20,0$ & $64,7 \pm 25,3$ & $<0,0001^{*}$ \\
\hline BoP (średnia $\pm \mathrm{SD})(\%)$ & $49,9 \pm 29,9$ & $39,2 \pm 26,1$ & $0,0026^{*}$ \\
\hline PD (średnia \pm SD) (n) & $2,9 \pm 1,1$ & $2,2 \pm 0,8$ & $<0,0001^{*}$ \\
\hline CAL (średnia \pm SD) (n) & $4,2 \pm 2,0$ & $2,5 \pm 1,5$ & $<0,0001^{*}$ \\
\hline CPI (n, \%) & $12(8,96)$ & $49(31,62)$ & \\
$1-2$ & $52(38,8)$ & $62(40)$ & $<0,0001^{* *}$ \\
3 & $70(52,24)$ & $44(28,38)$ & \\
\hline Liczba osób bezzębnych (n, \%) & $17(11,3)$ & $4(2,5)$ & $0,0021^{* *}$ \\
\hline
\end{tabular}

and the control groups was the highest in the C group according to Eichner, and accounted for 29.1 percentage points ( $36 \%$ for the study group and $6.9 \%$ for the control group). The Pearson's chi-squared test in this group set $\mathrm{p}$ at $<0.001$. Considering division into subgroups, the biggest discrepancy in group $\mathrm{C}$ occurred i z grupy kontrolnej była największa w grupie C wg Eichnera, i wynosiła 29,1 punktu procentowego (36\% dla grupy badanej i 6,9\% dla grupy kontrolnej). Test zgodności w tej grupie wyznaczył p na poziomie $<0,001$. Rozpatrując podział na podgrupy największa rozbieżność $\mathrm{w}$ grupie $\mathrm{C}$ występowała w podgrupie $\mathrm{C} 1$ - tylko jeden 
in subgroup $\mathrm{C} 1$ - only one patient from the control group was assigned to this subgroup (Fig. 3, 4). Characteristics of the study group and control group supplemented with data on selected socio-economic indicators and habits and coexisting the most common civilization diseases is presented in Table 5. All variables except the age of patients were analysed statistically using the U Mann-Whitney test, and the differences were statistically significant. Table 6 contains information obtained from a thorough periodontal examination carried out in all patients. The results of these studies clearly indicate a much worse state of periodontal tissues in the study group, which had its impact in statistical calculations based on the Mann-Whitney U test and $\chi 2$, where all the compared variables (PI, BoP, PD, CAL, CPI) were significantly different.

\section{Discussion}

The study shows that the prosthetic treatment needs in the study group are higher compared to the control group, however, in both groups the oral cavity conditions relative to the number of missing teeth is far from ideal. It was clearly shown that patients from the study group not only have fewer teeth, but also their distribution and type of dental deficiencies determine the greater extent of prosthetic restorations. In the control group, there were also huge needs of prosthetic treatment, however, the characteristics of deficiencies were limited to qualitative and interdental deficits (Class I and II according to Galasińska-Landsbergerowa) and almost half of this group, even in the absence of more than one tooth, had all four occlusal supporting zones (group A by Eichner). Authors of this study did not find analogous research in the literature; articles that have been found, somehow parallel in the diagnosis of missing teeth and their specific classification according to Eichner, correspond pacjent z grupy kontrolnej został przypisany do tej podgrupy (ryc 3,4$)$.

Charakterystyka grupy badanej i grupy kontrolnej wzbogacona o informacje odnośnie niektórych wskaźników socjoekonomicznych oraz nawyków i współtowarzyszących najczęściej występujących chorób cywilizacyjnych została przedstawiona $\mathrm{w}$ tabeli 5 . Wszystkie zmienne oprócz wieku pacjentów zostały przeanalizowane statystycznie wykorzystując test U Manna-Whitneya i różnice były istotne statystycznie. W tabeli 6 zamieszczono informacje pozyskane z dokładnego badania periodontologicznego przeprowadzonego u wszystkich pacjentów. Wyniki tych badań jednoznacznie przesądzają o dużo gorszym stanie przyzębia w grupie badanej co miało swoje przełożenie w obliczeniach statystycznych na podstawie testu U Manna-Whitneya oraz $\chi^{2}$, gdzie wszystkie porównywane zmienne (PI, BoP, PD, CAL, CPI) były istotnie różne.

\section{Omówienie}

Przeprowadzone badanie wskazuje, że potrzeby leczenia protetycznego $\mathrm{w}$ grupie badanej są zwiększone w porównaniu do grupy kontrolnej, jednak w obu grupach stan jamy ustnej pod względem braków w uzębieniu jest alarmujący. Jednoznacznie zobrazowano, że pacjenci z grupy badanej nie tylko posiadają ilościowo mniej zębów, ale również rozmieszczenie pozostałych w jamie ustnej zębów oraz charakter braków predestynuje do większej rozległości uzupełnień protetycznych. W grupie kontrolnej również występowały duże potrzeby leczenia protetycznego, jednak charakterystyka braków była w znaczącej części ograniczona do braków jakościowych i międzyzębowych (I i II klasa wg Galasińskiej-Landsbergerowej) i niemalże połowa tej grupy nawet w przypadku braku więcej niż jednego zęba posiadała wszystkie 4 strefy podparcia (grupa A wg Eichnera). Autorzy niniejszej pracy nie dotarli do analogicznych 
to the results obtained in this study. Miernik et al. studied prosthetic treatment needs in patients with end-stage renal disease (ESRD), obtaining statistically insignificant results but indicating a very bad situation in terms of prosthetic treatment both in the study group and in the general population. ${ }^{13}$ Thematically similar study was conducted by Castillo et al. and Brito et al., but they also did not find a statistically significant difference between the group of patients on dialysis and the healthy controls. ${ }^{14}$ In these studies, the authors searched for changes in the bone structure of the jaws, which could lead to disorders that accelerate tooth loss, unlike in the present study, in which the periodontal diseases factor is the link between cardiovascular diseases and premature loss of dentition. ${ }^{15}$ Aoyama et al., examining C-reactive protein and $\mathrm{IgG}$ levels of periodontal pathogens ( $P$. gingivalis, A. actinomycetemcomitans) in the Japanese showed that in patients with cardiovascular disorders, the number of residual teeth could be used as an adjunct to assess the severity of systemic inflammation. However, they did not take into account the location of missing teeth (classification of missing teeth) and thus did not indicate the specific needs of prosthetic treatment. ${ }^{16}$ Loss of teeth, resulting in a cascade of prosthetic treatment needs, is a form of disability, sometimes ignored and underestimated. Preservation of teeth is crucial for ensuring proper functioning and aesthetics of the stomatognathic system. Modern dental prosthetics, based on accurate diagnostics and proper planning, is not only able to fill missing teeth with different prostheses, but also to counteract pathologies resulting from these deficiencies. In full prosthetic rehabilitation, one cannot ignore the psychological aspect which, if properly stimulated, can convince the patient to work harder on oral health and maintain general health in the form of prohealth behaviours. In the examined group of badań $\mathrm{w}$ piśmiennictwie, jednak odnalezione prace $\mathrm{w}$ pewien sposób paralelne pod kątem rozpoznania braków zębowych oraz konkretnego ich sklasyfikowania wg Eichnera, korespondują z otrzymanymi wynikami. Miernik i wsp. badali potrzeby leczenia protetycznego u pacjentów ze schyłkową niewydolnością nerek (SNN, End-stage renal diseasae (ESRD)) otrzymując nieistotne statystycznie wyniki, jednak wskazujące na bardzo złą sytuację pod względem leczenia protetycznego zarówno u grupy badanej, jak i populacji ogólnej ${ }^{13}$. Zbliżone tematycznie badania zostały przeprowadzone przez Castillo $\mathrm{i}$ wsp. oraz Brito i wsp. - podobnie, nie odnaleźli oni statystycznie istotnej różnicy pomiędzy grupą pacjentów dializowanych a populacją kontrolną. ${ }^{14,15} \mathrm{~W}$ badaniach tych autorzy doszukiwali się zmian w strukturze kości szczęk, która mogłaby prowadzić do zaburzeń przyspieszających utratę zębów, odmiennie niż w niniejszej pracy, w której to czynnik periodontopatii jest łączącym pomiędzy chorobami sercowo-naczyniowymi a przedwczesną utratą uzębienia. Aoyama i wsp. na podstawie badań białka C-reaktywnego oraz poziomu IgG periopatogenów (P.gingivalis, A.actinomycetemcomitans) u Japończyków dowiedli, iż u pacjentów z zaburzeniami sercowo naczyniowymi liczba zębów rezydualnych może posłużyć jako czynnik wspomagający przy oszacowaniu nasilenia ogólnoustrojowego stanu zapalnego, nie brali oni jednak pod uwagę rozmieszczenia (klasyfikacji braków) zębów a tym samym nie wskazywali konkretnych potrzeb leczenia protetycznego. ${ }^{16}$

Utrata zębów, skutkująca kaskadą potrzeb leczenia protetycznego jest formą niepełnosprawności, czasami nieuświadomioną, a niekiedy bagatelizowaną. Zachowanie zębów jest kluczowe dla zapewnienia odpowiedniej funkcji oraz estetyki układu stomatognatycznego. Współczesna protetyka stomatologiczna, opierająca się na dokładnej diagnostyce oraz odpowiednim planowaniu, jest w stanie nie tylko uzupełnić braki zębowe o różnej charakterystyce, 
people with acute coronary syndromes, the need of such treatment is very high. At the same time, it is worth pointing out that the oral cavity condition in the general population is also alarming. ale również przeciwdziałać następującym w skutek tych braków patologiom. W pełnej rehabilitacji protetycznej nie można zapominać o aspekcie psychologicznym, który odpowiednio stymulowany może przekonać pacjenta do większej pracy nad zdrowiem nie tylko jamy ustnej, ale także ogólnym, w postaci zachowań prozdrowotnych. W przebadanej grupie osób z zaburzeniami w postaci ostrych zespołów wieńcowych potrzeby takiego leczenia są bardzo duże, jednocześnie warty zaznaczenia jest stan uzębienia w grupie przedstawicieli populacji ogólnej, który również jest alarmujący.

\section{References / Piśmiennictwo}

1. Lockhart PB, Bolger AF, Papapanou PN, Osinbowale $O$, Trevisan $M$, Levison $M E$, Taubert KA, Newburger JW, Gornik HL, Gewitz MH, Wilson WR, Smith SC Jr, Baddour $L M$ : Periodontal disease and atherosclerotic vascular disease does the evidence support an independent association?: a scientific statement from the American Heart Association. Circulation. 2012; 125: 2520-2544.

2. Humphrey LL, Fu R, Buckley DI, Freeman M, Helfand $M$ : Periodontal disease and coronary heart disease incidence: a systematic review and meta-analysis. J Gen Int Med 2008; 23: 2079-2086.

3. Janket SJ, Baird AE, Chuang SK, Jones JA: Meta-analysis of periodontal disease and risk of coronary heart disease and stroke. Oral Surg Oral Med Oral Pathol Oral Radiol Endod 2003; 95: 559-569.

4. Wojtyniak B, Goryński P, Moskalewicz B: Sytuacja zdrowotna ludności Polski i jej uwarunkowania. Narodowy Instytut Zdrowia Publicznego. Państwowy Zakład Higieny, Warszawa; 2012.

5. Górska R, Pietruska M, Dembowska E,
Wysokińska-Miszczuk J, Włosowicz M, Konopka T: Prevalence of periodontal disease in 35-44 year-olds in the large urban agglomeration. Dent Med Probl 2012; 49: 1927.

6. Konopka T, Dembowska E, Pietruska M, Dymalski P, Górska R: Periodontal status and selected parameters of oral condition of poles aged from 65 to 74 years. Przegl Epidemiol 2015; 69: 537-542.

7. Włosowicz M, Wożakowska-Kapłon B, Górska R: Oral health status in patients with myocardial infarction and patients with stable angina. Now Stom 2012; 2: 75-79.

8. Bochniak M, Sadlak-Nowicka J, Rynkiewicz A, Kusiek A: Relationship between periodontal status and the incidence of acute myocardial infarction. J Stomatol 2011; 64: 579-597.

9. Mielczarek A, Gozdowski D, Zduniak A, Hajdo A, Rusyan E: Stan uzębienia dorosłych Polaków na podstawie Monitoringu Stanu Zdrowia Jamy Ustnej i Jego Uwarunkowań w 2017 roku w regionie Mazowsza. Stom Współ 2018; 25, 1: 16-20.

10. Górska R, Konopka T: Periodontologia współ- 
czesna, Med Tour Press International, Otwock 2013, 53-55.

11. Majewski S: Współczesna protetyka stomatologiczna, Elsevier Urban \& Partner, Wrocław 2014, 101-102.

12. Spiechowicz E: Protetyka stomatologiczna, PZWL, Warszawa 2010, 84-89.

13. Miernik M, Madziarska K, Klinger M, Weyde $W$, Więckiewicz $W$ : The assessment of prosthetic needs of ESRD patients and the general population in Poland on the basis of the Eichner classification and teeth number: A brief, preliminary report. Adv Clin Exp Med 2017; 26(5): 777-780.

14. Castillo A, Mesa F, LiébanaJ, et al: Periodontal and oral microbiological status of an adult po- pulation undergoing haemodialysis. Oral Dis 2007; 13: 198-205.

15. Brito F, Almeida S, Figueredo CM, et al: Extent and severity of chronic kidney disease patients. J Periodontal Res 2012; 47: 426-430.

16. Aoyama N, Suzuki J-I, Kobayashi $N$ et al.: Associations among tooth loss, systemic inflammation and antibody titers to periodontal pathogens in Japanese patients with cardiovascular disease. J Periodont Res 2018; 53: 117122.

Zaakceptowano do druku: 7.02.2019 r.

Adres autorów: 00-257 Warszawa, ul. Miodowa 18.

(c) Zarząd Główny PTS 2019. 